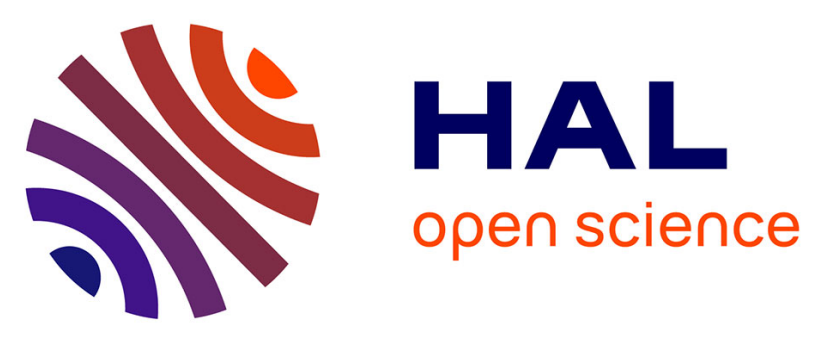

\title{
THU0119 Impact of Amino-Pva Coated Nanoparticles on Viability and Cytokine Secretion of Human Immune Cells Obtained from Healthy Donors and Patients with Rheumatoid Arthritis
}

\author{
C. Strehl, T. Gaber, M. Jakstadt, M. Hahne, P. Hoff, Lionel Maurizi, H.
}

Hofmann, G.-R. Burmester, F. Buttgereit

\section{To cite this version:}

C. Strehl, T. Gaber, M. Jakstadt, M. Hahne, P. Hoff, et al.. THU0119 Impact of Amino-Pva Coated Nanoparticles on Viability and Cytokine Secretion of Human Immune Cells Obtained from Healthy Donors and Patients with Rheumatoid Arthritis. Annals of the Rheumatic Diseases, 2014, 73 (Suppl 2), pp.219.1-219. 10.1136/annrheumdis-2014-eular.1379 . hal-02163542

\author{
HAL Id: hal-02163542 \\ https://hal.science/hal-02163542
}

Submitted on 11 Mar 2021

HAL is a multi-disciplinary open access archive for the deposit and dissemination of scientific research documents, whether they are published or not. The documents may come from teaching and research institutions in France or abroad, or from public or private research centers.
L'archive ouverte pluridisciplinaire HAL, est destinée au dépôt et à la diffusion de documents scientifiques de niveau recherche, publiés ou non, émanant des établissements d'enseignement et de recherche français ou étrangers, des laboratoires publics ou privés. 
active form of MTX-polyglutamate (PG), and MTX-PG has been reported to be possibly useful to monitor clinical response. ${ }^{1)}$ Moreover, it appears that good clinical response and adverse events such as liver injury are more often observed in Japanese patients with RA with very low dose of MTX (sometimes even 7.5-10 $\mathrm{mg} /$ week) than in Caucasian patients, suggesting MTX-PG concentrations are different between Japanese and Caucasians.

Objectives: To investigate if MTX-PG concentrations in erythrocyte in Japanese patients with rheumatoid arthritis (RA) are associated with disease activity or adverse events.

Methods: his multicenter prospective study has been conducted in Japan since Dec 2012. We enrolled 71 patients with rheumatoid arthritis diagnosed according to 2010 American College of Rheumatology (ACR)/European League Arthritis Rheumatism (EULAR) classification criteria, who had never been treated with MTX or biologic agents. MTX was started with a dose of $8 \mathrm{mg} /$ week with $5 \mathrm{mg} / \mathrm{week}$ folic acid and increased by $4 \mathrm{mg}$ by every 4 weeks until reached $16 \mathrm{mg} /$ week unless adverse events occurred. Blood samples were taken at baseline, week 4,8 and 12 , and after that every 12 weeks. MTX-PG 1-5 concentrations in the erythrocytes were measured using liquid chromatography. Clinical response and adverse events were collected from their charts, and the correlation between them and MTX-PG levels were analyzed.

Results: We analyzed MTX-PG1-5 concentrations from baseline to 12 weeks in 24 patients. The mean MTX doses at week 4,8 , and 12 were $7.8 \mathrm{mg} / \mathrm{w}$, $10.7 \mathrm{mg} / \mathrm{w}$, and $13.4 \mathrm{mg} / \mathrm{w}$, respectively. Mean SDAI was significantly decreased from $18.2 \pm 8.58$ at baseline to $7.50 \pm 5.84$ at week 12 . The proportion of patients at week 12 achieving low disease activity (SDAl $<11$ ) was $72.7 \%$. As MTX dose was increased, MTX-PG1-5 concentrations were increased (Fig. 1), and a high total concentration of total MTX-PG $(114.2 \mathrm{nmol} / \mathrm{L})$ could be obtained with relatively low dose of MTX $(13.4 \mathrm{mg} / \mathrm{w})$ at 12 week. The total MTX-PG concentration was significantly correlated with $\triangle \mathrm{SDAI}(\mathrm{R}=0.433, \mathrm{p}=0.044)$ (Fig. 2), and $\triangle \mathrm{HAQ}$ $(\mathrm{R}=0.610, \mathrm{p}=0.003)$. In this study, 9 patients $(19.5 \%)$ presented with hepatotoxicity. MTXPG1-5 concentration was higher in patients with hepatotoxicity than in those without (132.67 vs 117.23$)$, but this was not significant $(p=0.25)$ assumingly due to the small number of patients with hepatotoxicity.
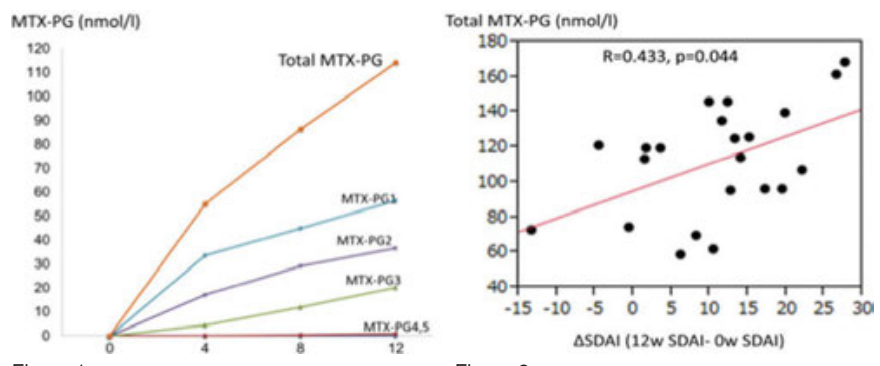

Figure 1 Figure 2

Conclusions: Japanese patients with RA showed high MTX-PG concentration in red blood cells with very low dose MTX, and the MTX-PG concentration might be useful to predict clinical response and hepatotoxicity during MTX treatment. References:

[1] Dalrymple JM, et al. Pharmacokinetics of oral MTX in patients with RA. Arthritis Rheumatism 2008; 58:3299-308.

Disclosure of Interest: None declared

DOI: 10.1136/annrheumdis-2014-eular.3527

\section{THU0119 IMPACT OF AMINO-PVA COATED NANOPARTICLES ON VIABILITY AND CYTOKINE SECRETION OF HUMAN IMMUNE CELLS OBTAINED FROM HEALTHY DONORS AND PATIENTS WITH RHEUMATOID ARTHRITIS}

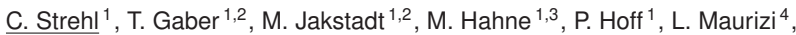
H. Hofmann ${ }^{4}$, G.-R. Burmester ${ }^{1}$, F. Buttgereit ${ }^{1,2}$. ${ }^{1}$ Department of Rheumatology and Clinical Immunology; ${ }^{2}$ Berlin-Brandenburg Center for Regenerative Therapies; ${ }^{3}$ Berlin-Brandenburg School for Regenerative Therapies, Charité University Medicine, Berlin, Germany; ${ }^{4}$ Institute of Materials Powder Technology Laboratory, École Polytechnique Fédérale de Lausanne (EPFL), Lausanne, Switzerland

Background: Nanotechnology has developed into a key technology of the 21st century. Over the recent years, the number of nanotechnical products has received an enormous boost. Furthermore, nanotechnology in medical applications provides new opportunities for diagnostic and therapeutic interventions in a variety of human diseases. Especially in rheumatoid arthritis (RA) an early diagnosis is still missing, although the treatment is most effective when started early. However, safety aspects still represent crucial problems for the further development of nanotechnology based products. Therefore, the focus of our work here was to identify putative effects of amino-PVA-coated super paramagnetic iron oxide nanoparticles (SPION) on human immune cell functions.

Objectives: We analysed the effects of various concentrations of PVA coated SPION on cell viability and cell activation with regard to cytokine secretion in a whole blood assay.
Methods: Venous blood, obtained from 18 healthy donors (HD) or 19 patients suffering from RA was collected. Whole blood was diluted 1:1 with RPMI 1640 culture medium in deep-well-plates, and cells were stimulated with LPS $(1 \mu \mathrm{g} / \mathrm{ml})$, PHA $(5 \mu \mathrm{g} / \mathrm{ml})$, PVA-SPION $(1 \mu \mathrm{g} / \mathrm{ml}, 10 \mu \mathrm{g} / \mathrm{ml}, 100 \mu \mathrm{g} / \mathrm{ml}, 1000 \mu \mathrm{g} / \mathrm{ml})$ or left untreated for $20 \mathrm{~h}$ at $37^{\circ} \mathrm{C}$. Cells were analysed for viability by flow cytometry, and supernatants were collected for quantification of cytokines via Bio-Plex ${ }^{\circledR}$ suspension array system. Cell viability was analysed by a combined staining for cell specific surface markers (CD3; CD14; CD15; CD19) and apoptotic and dead cells using Annexin V and 7AAD. As a second approach, intracellular IL1 $\beta$ was analysed to identify the main producers of IL1 $\beta$. Therefore, cellular transport was blocked by adding Brefeldin A to the whole blood 3 h prior to analysis.

Results: For both HD and RA, we did not find any significant influence on cell viability as induced by PVA-SPION at concentrations $<1000 \mu \mathrm{g} / \mathrm{ml}$. However, when analysing the impact of PVA-SPION on cytokine secretion, we demonstrated a significant dose dependent increase of several secreted cytokines in the cell culture supernatant (such as IL1 $\beta$, IL4, IL6, IL8 or MIP1b for both HD and RA samples). When analysing IL1 $\beta$ secretion in more detail, we found a PVASPION concentration dependent increase in the percentage of IL1 $\beta$ positive cells. Furthermore, we observed that the major cell populations producing IL1 $\beta$ after incubation with PVA-SPION are CD15 positive granulocytes as well as CD14 positive monocytes.

Conclusions: PVA-SPION at concentrations up to $1000 \mu \mathrm{g} / \mathrm{ml}$ do not increase the frequencies of apoptotic or dead human immune cells but do induce a PVA-SPION dose dependent cytokine secretion. We conclude that PVA-SPION represent a promising diagnostic and possibly also a therapeutic tool in rheumatic diseases, but prior to clinical use the impact of PVA-SPION on other human immune cells and the induction of cytokine secretion has to be further evaluated.

Disclosure of Interest: None declared

DOI: 10.1136/annrheumdis-2014-eular.1379

\section{THU0120 IS EARLY DMARD USE ASSOCIATED WITH LESS JOINT REPLACEMENT SURGERY? AN ANALYSIS OF 5,199 INCIDENT RHEUMATOID ARTHRITIS (RA) PATIENTS}

C. Moura $^{1}$, M. Abrahamowicz ${ }^{1}$, M.-E. Beauchamp ${ }^{1}$, D. Lacaille ${ }^{2}$, Y. Wang $^{1}$, C. Bombardier ${ }^{3}$, J. Widdifield ${ }^{4}$, J.G. Hanly ${ }^{5}$, G. Boire ${ }^{6}$, D. Feldman ${ }^{7}$, W. Maksymowych ${ }^{8}$, C. Peschken ${ }^{9}$, C. Barnabe ${ }^{10,11}$, S. Edworthy ${ }^{10}$, P.R. Fortin ${ }^{12}$, L. Bessette ${ }^{12}, \mathrm{H}$. Behlouli ${ }^{1}, \mathrm{~S}$. Bernatsky ${ }^{1} .{ }^{1}$ Division of Clinical Epidemiology, McGill University, Montreal; ${ }^{2}$ Department of Medicine, University of British Columbia, Vancouver; ${ }^{3}$ Division of Rheumatology, University of Toronto; ${ }^{4}$ Institute for Clinical Evaluative Sciences, Toronto; ${ }^{5}$ Division of Rheumatology, Department of Medicine, Dalhousie University, Halifax; ${ }^{6}$ Département de Médecine, Université de Sherbrooke, Sherbrooke; ${ }^{7}$ École de Réadaptation, Université de Montréal, Montreal; ${ }^{8}$ Department of Medicine, University of Alberta, Edmonton; ${ }^{9}$ Department of Internal Medicine, University of Manitoba, Winnipeg; ${ }^{10}$ Department of Medicine; ${ }^{11}$ Department of Community Health Sciences, University of Calgary, Calgary; ${ }^{12}$ Département de Médecine, Université Laval, Laval, Canada

Background: Early DMARD use in RA may prevent damage and possibly, need for joint replacement.

Objectives: To assess joint replacements within incident RA patients in Quebec, Canada, and potential associations with early DMARD use.

Methods: A cohort of incident RA patients was identified from Quebec's physician billing and hospitalization databases from 2002-2008; all patients covered by the provincial drug insurance for the duration of the study were included in analyses. We used Cox regression with time-dependent variables for: 1) methotrexate (MTX) use, 2) other non-biologic DMARDs and 3) anti-tumor necrosis factor (TNF) agents. Models were adjusted for baseline sociodemographic characteristics, comorbidity including pre-existing osteoarthritis, and prior health service use, and for time-dependent variables reflecting cumulative use of other drugs (COXIBs, NSAIDs, and systemic steroids) and time-dependent indicators of disease severity (extra-articular RA features and number of rheumatology visits). The outcome (any joint replacement) was defined using procedure codes.

Results: During follow-up, 321 joint replacements occurred among 5,199 incident RA patients observed for a total of 19,693 years ( 1.6 events/100 person-years). The best-fitting models relied on cumulative duration of MTX and cumulative duration of non-MTX traditional DMARD use in the first year after RA diagnosis. Controlling for anti-TNF exposure, joint replacement rates throughout follow-up appeared to be significantly lower with greater cumulative MTX and with greater cumulative non-MTX traditional DMARD use in the first year of RA (Hazard ratio, $\mathrm{HR}=0.95$ per month of MTX use, $95 \%$ Confidence Interval, $\mathrm{Cl} 0.91-0.98 ; \mathrm{HR}=0.93$ per month of use of non-MTX traditional DMARDs, 95\% CI 0.90-0.97). However, patients receiving both MTX and non-MTX traditional DMARDs, concurrently or sequentially, within the first year after RA onset, had a significantly higher risk of joint replacement than those who used only one of the two drug classes within the first year. We could not establish independent effects for anti-TNF agents.

Conclusions: Higher cumulative use of MTX and higher cumulative use of non-MTX traditional DMARDs within the first year after RA diagnosis appeared to be associated with fewer joint replacements. This may be consistent with joint-sparing effects of aggressive, early use of these drugs, though a causal link cannot be established with these observational data. The increased joint replacement risk in patients taking both MTX and other DMARDS, concurrently 